\title{
The practice of different structural systems in Cypriot architecture from pre-historic to modern times
}

\author{
G. Ozay ${ }^{1} \&$ N. Ozay ${ }^{2}$ \\ ${ }^{1}$ Department of Civil Engineering, \\ Eastern Mediterranean University, Northern Cyprus \\ ${ }^{2}$ Department of Architecture, \\ Eastern Mediterranean University, Northern Cyprus
}

\begin{abstract}
Cyprus is one of the oldest islands in the Mediterranean Sea, where human settlements can be traced. Over the centuries, it was governed by different states. Under the influence of each cultural milieu various periods were developed in the history of Cyprus. Each period reflects the age and its social life style, economic conditions, technological opportunities, religion and political structure. Today, it is possible to observe lots of architectural examples from the various periods. Some of them have been demolished under the effects of time and physical factors. However, the strong and well-designed structures carried their most important parts to the present. In this study, the structural evolution is investigated under the influence of different architectural periods of Cyprus. It starts with the pre-historic times of the island and continues until the beginning of modern times. Various structural systems and building materials are all discussed bearing in mind the historical development and changing conditions of Cyprus. In other words, the practice of different structural systems in architecture is argued in related to the environment, social requirements and life styles which reflect the influences of the sustainable design.

Keywords: Cyprus, architectural periods, building materials, structural systems.
\end{abstract}

\section{Introduction}

Cyprus has a rich cultural heritage that is at the cross roads of three continents Europe, Asia and Africa. From pre-historic to modern times it has constructed 
the architecture layer by layer in harmony with the cultural, environmental and technological factors. Even today, the traces of the variable civilizations and their efforts can be observed on the existing buildings. According to the historical movement, the effects of the conquering states and architectural tendencies, the structural systems and building materials reflected different characteristics. In this study, the evolution of different structural systems in Cypriot architecture is intended to be discussed from pre-historic to the beginning of the modern times. It is possible to evaluate the structural systems in four main groups such as Ancient Times, The Medieval Period, The Ottoman and British Periods. Under the influence of each, different periods developed variable architectural characteristics. However, some of the periods attached more importance to architecture than others and left more significant structures from their time.

\section{Ancient times}

Ancient times of Cyprus consist of variable sub periods such as The Stone Age, Bronze Age (Copper Age), Iron Age, Hellenistic Period, and Roman Period. Thus, according to the historical developments and existing cultures of those times, architecture begins to flourish in the island. The appearance of the first signs of human life in Cyprus date back to nearly c. $8500 \mathrm{BC}$, during the Palaeolithic Period [1].

It is possible to say that early Neolithic man is a practical innovator. Most of the basic principles of structures were raised in the earliest Round House building. However, much of these building techniques were reached over from Syria or however much was evolved in Cyprus. Such buildings were built by every possible structural system: both as load bearing and as framed structures [2].

Traces of the early communities are seen all over the island, such as those at Khirokitia, Sotira, Vrysi, Kalavassos Ayious, Erimi, Lemba and Lakkous [2]. Khirokitia (5800 BC / Neolithic) is the first known urban settlement, which reflects the properties of prehistoric architecture and structural properties.

Khirokitia is composed of circular houses. The dwellings uncovered at this site were of the tholos type (round beehive-shaped huts) [3]. Small undressed stones were used for the lower structure of the houses and sun-dried mud bricks and clay was used for the middle parts and superstructure. Generally, the roof was dome shaped (Fig.1). However, recently one building was found to have had a flat roof [4]. The houses of Khirokitia were organised to be close to each other. It is believed that every family had two or more circular buildings for different activities.

The external diameter of these round structures varied between $2.3 \mathrm{~m}$ to $9.2 \mathrm{~m}$. Internal diameter was between $1.4 \mathrm{~m}$ and $4.80 \mathrm{~m}$ [6] (Fig.2). Each circular unit was divided into different spaces according to function. The interior walls were made of plastered mud. In many cases, evidence of piers was found suggesting supports to an upper floor. 


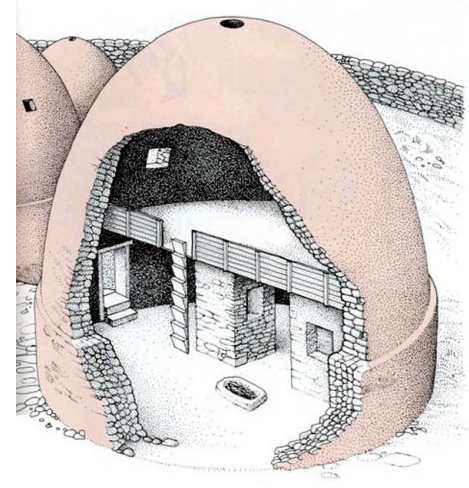

Figure 1: A three-dimensional image from a house of Khirokitia [5].

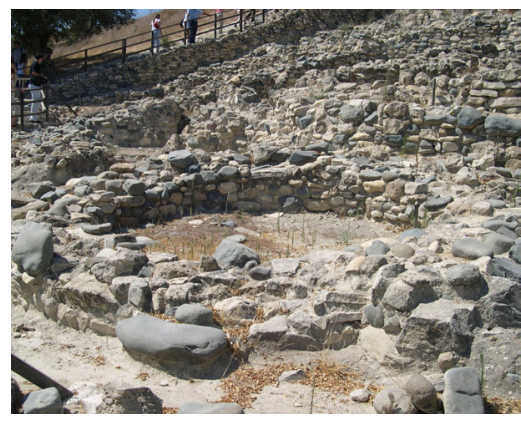

Figure 2: $\quad$ Traces from the Khirokitia settlement.

Around 6000 BC, Khirokitia was suddenly abandoned for unknown reasons. Thus, the island remained uninhabited for about 1500 years until the next recorded settlements known as the Sotira group (4500-4000 BC) appears. Sotira consists of nearly fifty, single room houses [1]. The tholoi type rectangular dwellings were the scheme adopted at Sotira (Fig.3) [3]. Generally, the houses were freestanding, with relatively thin walls. They tended to be square with rounded corners, different from the roundhouse buildings of Khirokitia.

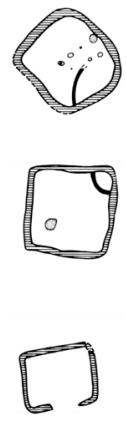

Figure 3:

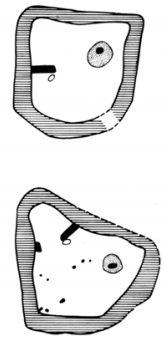

Typical architecture of Figure 4: the Sotira group [7].

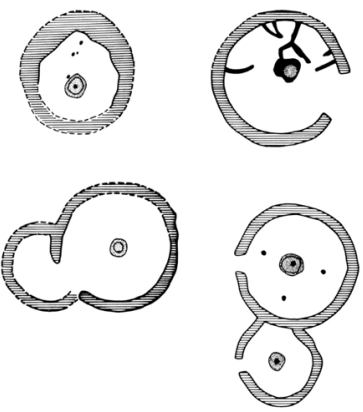

Typical architecture of the Erimi group [7].

The Chalcolithic Period (3900-2600 BC) followed the Neolithic. The most important development of this period is the discovery and use of copper. Generally, the circular houses of the Neolithic Period continued to be built during this age as well. New settlements such as Erimi, Lapithos and Kythrea were built indicating an increase of population (Fig.4).

The first towns and economic centres of Cyprus start to be formed during the Early Bronze Age (2300-1850 BC) around the copper sources. Cyprus also 
developed commercial and cultural relations with Asia Minor, Egypt, and the Syrian/Palestinian region during this period. These relations caused migrations of people from Anatolia to Cyprus [8]. In addition, around $1200 \mathrm{BC}$, new immigrations take place by Mycenaean and Achaean Greeks. They brought to Cyprus Hellenic language, culture and religion. The arrival of the Achaeans greatly influenced town planning, architecture and pottery [3].

Like the Early Bronze Age, multi-roomed buildings replaced single structures in the Middle Bronze Age (1900-1600 BC). Individual units usually had two rooms (sometimes subdivided) one for habitation and one for storage, which was reached from a corridor or perhaps, through an open space in front [9].

At the beginning of the Late Bronze Age (1650-1050 BC), the flourishing of commercial centres is observed [10]. This was a period for sophisticated literate city-states such as Enkomi-Alasia and Kition. Moreover, Cyprus became a crossroad of the eastern and western cultures.

In general, the properties of this age were reflected in city and tomb architecture. Cities were abandoned or fortified, destroyed and rebuilt [8]. In the Late Bronze Age, the most significant architectural development is the town planning of Enkomi. The streets of the town crossed each other at right angles creating a grid plan (Fig.5). Houses of Enkomi had several rooms, which were organised, around a central courtyard. Bathrooms had cemented floors and Enkomi had lavatories as well as an elaborate drainage system [9].

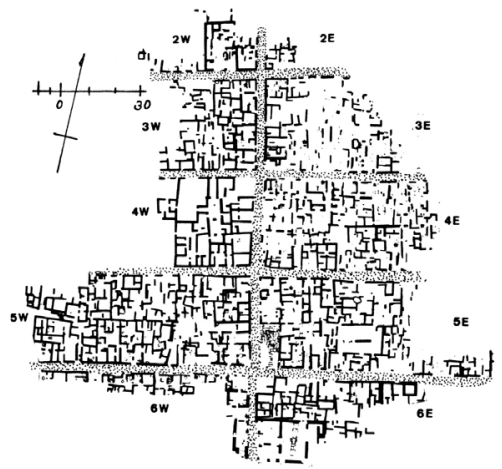

Figure 5: $\quad$ Grid plan of Enkomi (Late Bronze) [11].

The period between 1050 and $850 \mathrm{BC}$ are known as the "Dark Age" for Cyprus. There is not enough information about the first centuries of the Iron Age and its architecture. One of the most significant points of the Geometric Period (1050-750 BC) of the Iron Age is that iron had already been in use in Cyprus since $1050 \mathrm{~s}$.

Tombs were the most expressive buildings of the Archaic Period (750$475 \mathrm{BC})$ that reflected the ability of Cypriot architects and masons. Public buildings were built of fine ashlar masonry, with mud-mortar. On the other hand, domestic buildings were less sophisticated with rectangular or apsidal rooms. 
They were constructed mostly from mud-brick on rubble foundations set in mudmortar [9].

For more than a century during the Classical Period (475-325 BC), the government of Cyprus generally changed hands between Greece and Persia [3]. However, we do not come across any definitive architectural contribution in Cyprus by Persians.

During the Hellenistic Period (325-58 BC), more than two hundred years of Persian rule was terminated with the success of Alexander the Great. On this basis, the island stayed under the control of the Hellenistic Rule until the Roman annexation [3].

Most of the public and private buildings collapsed during the earthquakes of $15 \mathrm{BC}$ and 76/7 AD. The theatre in Kourion was built in the second century (Fig.6). It has a Greek type plan with an orchestra greater than a semi-circle and a high proscenium that was supported by half-columns [9].

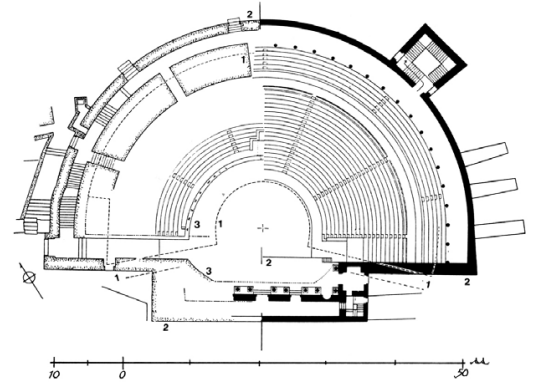

Figure 6: $\quad$ The theatre in Kourion Figure 7: (Hellenistic) [11].

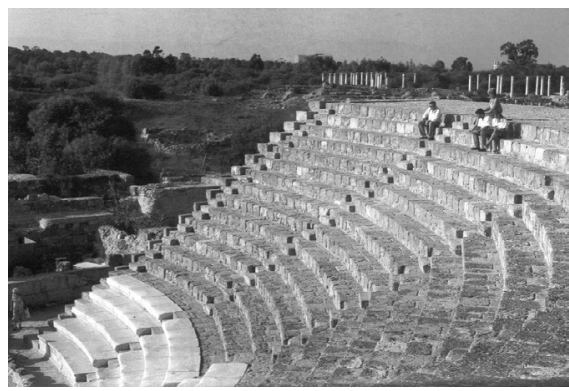

Theatre of Salamis (Roman) [10].

Public buildings were mostly constructed in ashlar masonry. Two storey buildings usually had a superstructure of mud-brick on thick foundation walls (with an outer face of ashlar blocks).

In 58 B.C, Cyprus came under the domination of the Roman Empire. In the Roman Period (58 BC-330 AD), the island was governed by a proconsul and divided into four districts: Amathus, Lapithos, Paphos, and the centre of commerce at Salamis. Romans started to build new roads, harbours, and public buildings in Cyprus. Public buildings such as market places, gymnasia, public baths, theatres, amphitheatres for gladiatorial contests and nymphaea (fountain houses) were organised together and created a city centre. Also, Paphos supplanted Salamis as the capital (Fig.7) [12]. Roman amphitheatres, public baths, mosaics and other architectural events were the most significant evidences from that period. Engineering innovations of the Roman Period such as vaults, domes, arches, etc. can be observed on the existing buildings. Aqueducts were used to bring a good water supply in this era [9].

Generally, most of the Roman houses were of modest size, but they were decorated with mosaic floors. The rooms of these houses were arranged around a central (colonnaded) courtyard. 


\section{The medieval times (middle ages)}

The Roman Empire was divided date into two parts as Eastern and Western. As a result of this division Cyprus became part of the Eastern Roman Empire to be known as Byzantine Period (330-1191). After the appearance of Islam in the sixth and seventh centuries AD, Cyprus started to play an important role between Christendom and Islam. In the latter three hundred years, Cyprus changed hands many times between the Arabs and Byzantine Empire.

As a whole, Byzantine Period is considered to be very prolific, its art reflecting the prosperity of the age. However, not much remains of the works carried out at the time. Generally, domes, arches and vaulting systems are the main structural elements of the Byzantine Period. One of the major works of the period is St. Barnabas Church and Monastery from early tenth century (Fig.8). The solid stone structure of the building reflects the significant characteristics of the era with its domes, barrel vaults and arches.
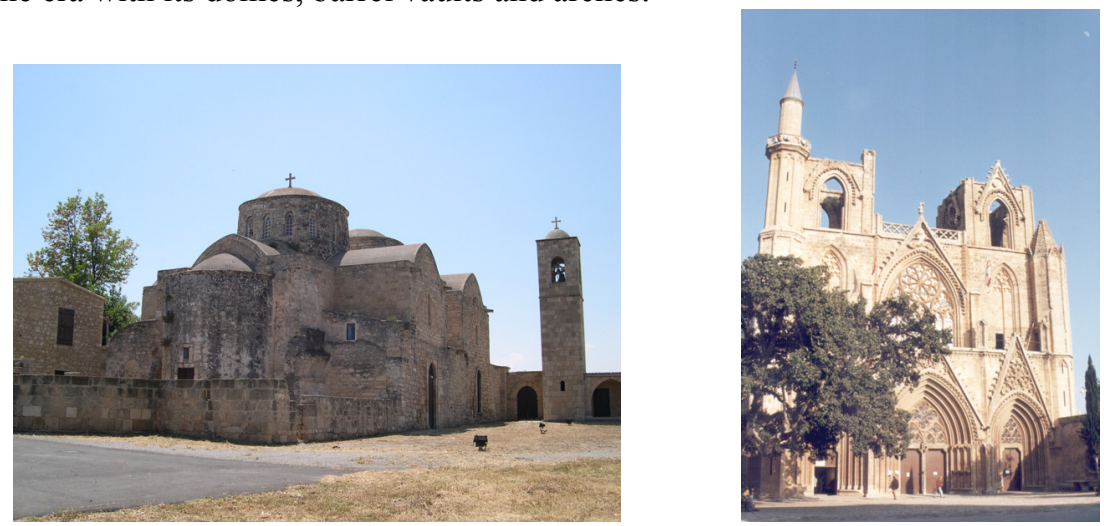

Figure 8: The five-domed church of St. Figure 9: St. Nicholas Cathedral. Barnabas.

The western Crusaders also affected the history of Cyprus, at that time. In 1191 during the Third Crusade, Richard the Lion-heart, King of England captured the island. Thus, Cyprus came under the rule of the English King. However soon after, the island changed hand to the Frankish King of Jerusalem, Guy de Lusignan (1192 BC). The following three centuries were the most brilliant times of Cyprus history, known as the Lusignan Period (1192-1489).

Under the influence of the Lusignans, the island would be an important place famous for its architectural creations. Generally, churches, monasteries, palaces and mansions were built at that time. Buildings that have fine wall paintings and mosaics create a significant part of the Lusignan architecture.

The common architectural style of Lusignans is Gothic. From the smallest piece to the largest, they used the structural elements properly and created perfect architecture. Pointed arches, piers, rib vaults and flying buttresses are some of the important structural elements that make the monuments higher and more transparent. Some of the major historical buildings that belong to the 
Lusignan Period are St. Nicholas' Cathedral in Famagusta, St. Sophia's Cathedral in Nicosia, Bellapais Abbey, Our Lady of Tyre and Kyrenia Castle (Fig. 9).

During the Venetian Period (1489-1571) that followed, the island became an important trading post and strategic military outpost against Muslim attacks. Venetians generally expressed a militaristic character and gave importance to the defence of Cyprus. Therefore, the architecture of the island was shaped in a different way. They did not lose time and fortified their cities. In Famagusta, new walls were replaced with massive bastions. Between 1567 and 1570, they also constructed the walls that are still standing around Nicosia. Most of the architectural buildings of that time are of a military nature. However, there are also few that have different functions, Queen's House, Bidulb Gate and some dwellings can be given as examples for these [13]. Generally, these buildings were built with stone load bearing construction method. The Lapidary Museum at Nicosia, which is also known as the Venetian House, is an example for the dwellings of the Venetian Period (Fig.10).

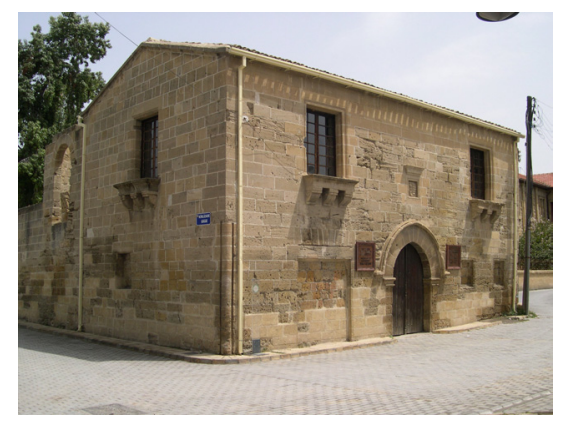

Figure 10: Venetian House (the Lapidary Museum).

\section{The Ottoman Period (1571-1878)}

During the Ottoman Period (1571-1878), timber framed structure was the common traditional method. The residential buildings of this period are known as "Traditional Turkish Houses". They all reflect the general features of the timber framed structure. The use of these structures was mostly utilised as a hybrid structure together with the infill materials. According to the different use of infill materials, the timber framed structures can be divided into two groups. These are "Baghdadi" and "Himish". In the Baghdadi type, long narrow strips of wood or bamboo (reeds) were nailed on to the timber frames (Fig.11). This method was used in the structure of walls. In addition, its light system, made it possible to use for the ceilings and bay windows. In the Himish type structures, the timber frame was filled with adobe or stone (Fig.12). Both Baghdadi and Himish structures were plastered with lime from their exterior and interior surfaces [14]. Mostly, the foundations of these buildings were stone, which had origin as from the ancient times such as Lusignan (1192-1489) and Venetian 
(1489-1571) [15]. These foundations were built by sandstone of the dimensions, to $1 \mathrm{~m}$ or $1.2 \mathrm{~m}$ (roughly $3 \mathrm{ft}$ or $4 \mathrm{ft}$ ) [16]. In this way, the buildings were protected against water and moisturising.

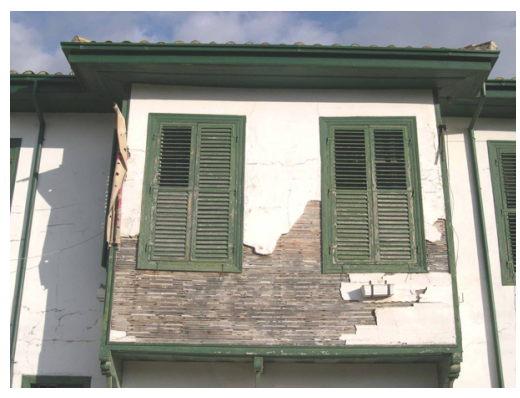

Figure 11: The Baghdadi type Figure 12: structure.

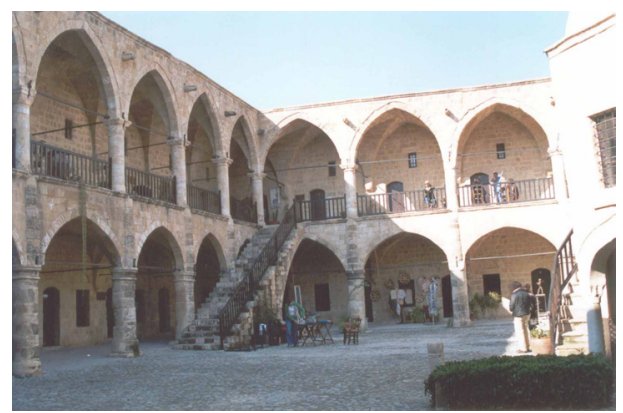

Figure 13: The Great Inn.

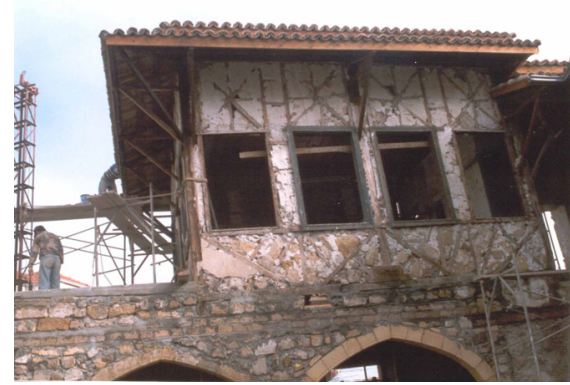

The Himish type timber framed structure [17].

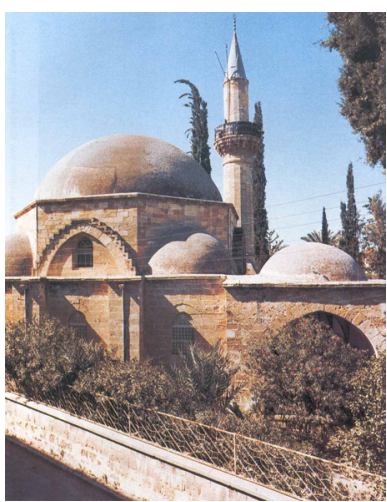

Figure 14: Arabahmet Mosque [18].

Monumental buildings of the Ottoman Period (1571-1878) such as; mosques, inns and baths etc. were built with stone load bearing construction method as different from the residential buildings. Yellow stone is the local building material that was used for this type of buildings. It is more durable material than adobe. Thus, it was preferred for such kind of large scaled buildings. The Great Inn (Buyuk Han) (Fig.13) and Arabahmet Mosque (Fig.14) in Lefkosa are some of the remarkable examples of this type structure. Arabahmet Mosque is one of the significant buildings from the Classical Ottoman architecture. It was built on to the foundation of a medieval church [10]. The large dome of $50 \mathrm{ft}$ across, rests on the main space and the entrance porch facing north is capped with three small domes. The Great Inn is a two-storey building, which was designed around a square courtyard. This courtyard was surrounded by the arcaded transition spaces 
both on the ground and first floors. Cross vaults cover these semi open spaces. Dome, arch and vault are considered as the significant elements of the frameless stone structures as mentioned in these examples.

\section{The British Period (1878-1960)}

During the British Period (1878-1960) different types of buildings such as residential, religional, offices and government buildings were all built through the use of the frameless structures. Yellow sand stone is the main building material of the period (Fig.15). Variety of applications such as; arcaded, ornamented, more naked and etc. can be found from the British Period. Besides, different patterns of the stone masonry helped improving the aesthetic quality. Timber was still the part of the constructions. Mostly, this material was used in the construction of doors, stutters, balustrades and roofs. At the end of the British Period, a new material, reinforced concrete, began to be used together with the yellow stone (Fig.16).

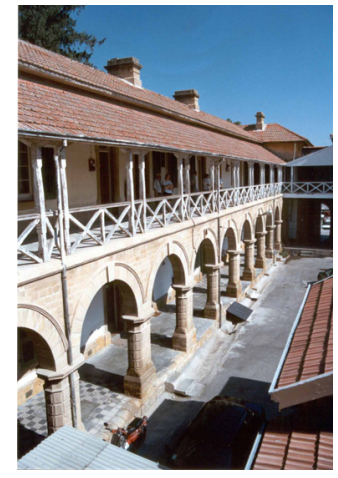

Figure 15: The Court Building of Lefkosa.

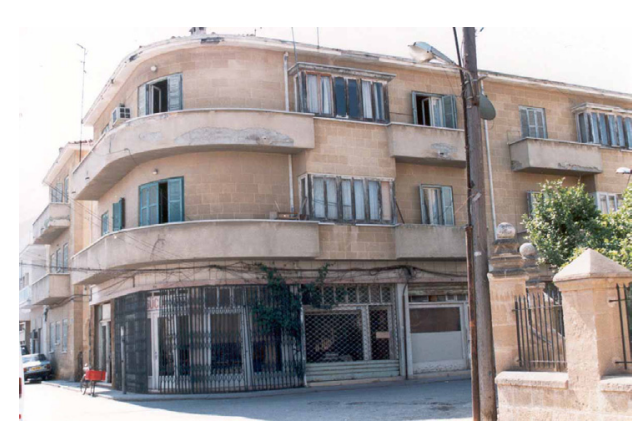

Figure 16: Load bearing stone walls with reinforced concrete elements.

\section{Conclusion}

From pre-historic times to the beginning of the Modernism, traditional construction techniques covered an important place in the Cypriot architecture. As discussed in the study, these techniques were formed as a result of a long period of accumulation of knowledge and experience. Generally, it is possible to classify the common traditional structures into two main groups such as timber framed structures (Baghdadi and Himish) and frameless structures (load bearing). Local materials such as mud brick (kerpich in Turkish that is formed by earth and straw) and stone were used to build these structures.

The early round houses of the Khirokitia settlement began to constitute the basic principles of the structural systems during Ancient Times. However, the most significant developments took place in Medieval Times by the end of the 
Roman Period. The building materials were also the same in these years. However, innovations in engineering improved the quality of architecture. The structural elements such as column, dome, arch and vault systems helped to construct more impressive buildings in larger scales. This development reached its highest level by the Gothic Style during the Lusignan Period (1192-1489). The traditional Turkish type residential buildings put their marks upon the Ottoman Period (1571-1878). The timber framed structures of these buildings made them considerable. During the British Period, yellow limestone and adobe were also the main building materials. Thus, the previous structural systems were commonly used due to changing life styles and architectural tendencies. However, during the last years of the British Period, concrete began to be used as a new material. Thus, the traditional structure systems started to lose their popularity. By the end of the British Period, reinforced concrete became the common structural system on the island.

The use of traditional construction methods and local building materials have lots of advantages such as economic, energy efficiency, environmental sensitivity, appropriateness of design and resistance to earthquake. In other words, they are environmentally responsive and have sustainable building designs. As discussed above, each period carried some of the valuable experiences to the other for improvement. Thus, the rich architectural heritage of Cyprus is an important guide for the future.

\section{References}

[1] Hunt, D., Footprints in Cyprus, London, p. 1, p. 5, 1990.

[2] Wright, G.R.H., Ancient Building in Cyprus, Vol. I (Text), The Netherlands, p. 36, p. 354, 1992.

[3] Watkins, P., See Cyprus, A Complete Guide with Maps, Format Books, p. 10, p. 11, 1972.

[4] McCarta, \& Verlag, N., Cyprus, Kranj-Slovenia, p. 17, 1993.

[5] Hawkes, J., The Atlas of Early Man, London, 1977.

[6] Burn, L. E., Khirokitia, A Neolitic Site, Bank of Cyprus Cultural Foundation, Nicosia, p. 19, 1997.

[7] Peltenburg, E.J., Recent Developments in the Later Prehistory of Cyprus, Sweden, p.119, 1982.

[8] Schmidt, R., \& Worley, B., North Cyprus, London, p. 8, p. 10, 1991.

[9] Brown, V.T., Ancient Cyprus, London, p. 18, p. 20, p. 23, p. 27, 1997.

[10] Albrecht, P.J., North Cyprus, London, pp. 58-59, p. 198, 1994.

[11] Wright, G.R.H., Ancient Building in Cyprus, Vol. II (Illustrations), The Netherlands, p. 49, p. 144, 1992.

[12] Solsten, E., Cyprus: a country study, Federal Research Division, Library of Congress, Cataloging-in-Publication Data, Washington D.C., p. 9, 1993.

[13] Goulding, J., \& M., Northern Cyprus, Gloucestershire, p. 58, 1980.

[14] Hasol, D., Ansiklopedik Mimarlik Sozlugu, Yem Yayin, Istanbul, 1993.

[15] Salvator, L., Levkosia, The Capital of Cyprus, Trigraph, London, 1983. 
[16] Yapicioglu, A., Ottoman Influences on Cypriot Domestic Architecture (1571-1923), M.A Thesis in University of Kansas, 1990.

[17] Archive of the Department of Ancient Monuments and Museums, Lefkosa.

[18] Miralay, M., Lefkosa Turk Belediyesi, A-N Graphics, Lefkosa, 1991. 